\title{
Effect of Dietary Inclusion of Conjugated Linoleic Acid on Quality Indicators of Aged Pork Loin
}

\author{
Kristen E. Matak ${ }^{1}$, Kaitlin H. Maditz ${ }^{1}$, Kimberly M. Barnes ${ }^{1}$, Sarah K. Beamer ${ }^{1} \&$ P. Brett Kenney ${ }^{1}$ \\ ${ }^{1}$ Division of Animal and Nutritional Sciences, West Virginia University, Morgantown, WV, USA \\ Correspondence: Kristen Matak, Division of Animal and Nutritioanl Sciences, PO Box 6180, West Virginia \\ University, Morgantown, WV 26506-6108, USA. Tel: 1-304-293-1908. Email: kristen.matak@mail.wvu.edu
}

Received: March 12, 2013 Accepted: April 9, 2013 Online Published: May 15, 2013

doi:10.5539/jas.v5n6p1 URL: http://dx.doi.org/10.5539/jas.v5n6p1

\begin{abstract}
The purpose of this study was to examine the effect of dietary inclusion of conjugated linoleic acid (CLA) in hog feed on quality indicators of pork loins. A total of twenty barrows (PIC 380 x Cambrough 1025) were randomly paired, housed in pens, and fed $1 \%$ soybean oil or 1\% CLA diet for 6 weeks. There were no significant differences in proximate composition of the pork loins $(\mathrm{P}>0.05)$. Muscle $\mathrm{pH}$ increased and there were color changes over time $(\mathrm{P}<0.05)$ which was independent of $\operatorname{diet}(\mathrm{P}<0.05)$. Shear force decreased over time $(\mathrm{P}=0.017)$, with CLA loins having lower shear force than the control $(\mathrm{P}=0.032)$. These results indicate that CLA supplementation of finishing diets resulted in pork quality similar to that of traditional diets.
\end{abstract}

Keywords: conjugated linoleic acid, pork loin, muscle $\mathrm{pH}$, pork quality

\section{Introduction}

Meat marbling is defined as the intramuscular fat located in perimysial connective tissue between the muscle fiber bundles. Marbling is associated with increased quality, tenderness, and acceptability of meat (Aberle, Forrest, Gerrard, \& Mills, 2001). Leaner hogs have less intramuscular marbling which effects product quality (Lonergan et al., 2007); therefore, there is interest in the swine industry for strategies that would improve intramuscular fat deposition and increase marbling.

Soybean oil is a typical dietary source of fat in hog feed; however, in an effort to improve pork quality, the inclusion of various feed additives in the finishing diets have been examined, like conjugated linoleic acid (CLA) (Wiegand, Sparks, Parrish Jr., \& Zimmerman, 2002; Dugan, Kramer, \& Aalhus, 2004). CLA is known to have anticarcinogenic, antidiabetic, and altered lipid composition when supplemented in mammals (Brandebourg \& Hu, 2005). CLA is comprised of positional and geometric conjugated isomers of linoleic acid and are also shown to effect proliferation and differentiation of adipocytes (Jiang et al., 2010). Adipocyte differentiation is regulated by many transcription factors, and is strongly linked to peroxisome proliferator-activated receptor (PPAR $\gamma$ ) expression (Wolins et al., 2006). PPAR $\gamma$ is the main gene responsible for regulating the adipocyte specific genes and is required for adipose differentiation in mice (Rosen et al., 1999). Although the complete mechanism behind this gene expression regulator is not fully understood, various ligands (such as conjugated linoleic acid) have shown to decrease the activity of this gene, decrease subcutaneous preadipocyte formation, and increase intramuscular preadipocyte formation, or marbling (Moya-Camarena, Vanden-Heuvl, Blachard, Leesnitzer, \& Belury, 1999; Zhou et al., 2007).

Dietary inclusion of CLA in finishing feed is important to swine producers because it has been reported to reduce backfat and increase subjective marbling scores (Dugan, Aalhus, Jeremiah, Kramer, \& Schaefer, 1999; Dugan, Aalhus, Schaefer, \& Kramer, 1997; Wiegand, Larsen, Baas, Parrish, \& Swan, 2001). A positive relationship exists between intramuscular lipid content and sensory attributes of pork such as texture, tenderness, flavor and juiciness (Lonergan et al., 2007); therefore, increasing marbling scores may positively impact fresh pork quality. Inclusion of unsaturated fatty acids in animal feed may cause meat to be softer and less shelf-life stable due to a greater predisposition to fatty acid oxidation (Larsen, Swan, Sparks, Wiegand, \& Parrish, 2009); however, CLA, also an unsaturated fatty acid, will improve growth rates of finishing hogs and increase the firmness of the meat (Larsen et al., 2009; Wiegand et al., 2002). Barnes, Winslow, Shelton, Hlusko and Azain (2012) showed that the loins of CLA-fed hogs had a greater proportion of saturated fatty acids and a slight increase of marbling when compared to 
non-CLA-fed hogs. More intramuscular saturated fat and increased marbling may improve meat palatability traits such as tenderness and flavor (Barnes et al., 2012).

In response to consumer demand for meats containing less saturated fat, the meat industry has produced hogs with lower hot carcass weights as well as less overall fat content. Leaner hogs have less intramuscular marbling, which negatively affects product quality (Lonergan et al., 2007); therefore, there is interest in the swine industry for strategies that would improve intramuscular fat deposition. Therefore, the objective of this study was to determine if the inclusion of CLA in finishing diets would affect quality indicators of pork Musculus longissimus dorsi muscle.

\section{Method}

\subsection{Animals and Diets}

All animal procedures were carried out according to the Animal Care and Use Committee Guidelines of West Virginia University (WVU) and are reported elsewhere (Barnes et al., 2012). Briefly, twenty barrows (PIC $380 \mathrm{x}$ Cambrough 1025$)$ of similar body weights $(53 \pm 5.61 \mathrm{~kg})$ and ages $(\sim 3$ months $)$ were housed at the WVU livestock farm for the duration of this study. Barrows were blocked by weight and assigned to pens of two hogs per pen (pen as experimental unit). Pens were randomly assigned diets (Table 1) containing either 1\% soybean oil (SBO diet; control) or 1\% CLA oil (LUTA-CLA, 60\% CLA isomers, 50:50 cis-9, trans-11 : trans-10, cis-12; BASF, Offenbach/Quiech, Germany) for a finishing period of 6 wks (Barnes et al., 2012).

Table 1. Diet formulation calculated (as-fed basis) of diets shown below. Both control and CLA diets only differed in the $10 \mathrm{~g} \mathrm{~kg}^{-1}$ oil additive

\begin{tabular}{|c|c|}
\hline Ingredient & Inclusion, $\mathrm{g} \mathrm{kg}^{-1}$ \\
\hline Corn & 849.9 \\
\hline Soybean meal & 108.3 \\
\hline Meat and bone meal & 21.1 \\
\hline $\mathrm{Oil}^{\mathrm{a}}$ & 10.0 \\
\hline Limestone & 6.5 \\
\hline Vitamin and trace mineral pre-mix ${ }^{\mathrm{b}}$ & 2.5 \\
\hline Salt & 1.7 \\
\hline Lysine & 0.05 \\
\hline
\end{tabular}

\section{Calculated analysis}

Crude protein, $\%$

$\mathrm{ME}, \mathrm{kcal} / \mathrm{kg}$

Lysine, \%

Calcium, \%

Phosphorus, available \%

${ }^{\text {a }}$ Soybean oil or CLA-60 (60\% CLA isomers, 50:50 c9, t11:t10, c12; provided by BASF) in their respective diet treatments.

${ }^{\mathrm{b}}$ Supplied per kilogram of diet: vitamin A, 7,716 IU; thiamin, $2.20 \mathrm{mg}$; riboflavin, $6.61 \mathrm{mg}$; niacin, $27.56 \mathrm{mg}$; pantothenic acid, $6.61 \mathrm{mg}$; vitamin $\mathrm{B}_{6}, 1.38 \mathrm{mg}$; biotin, $0.03 \mathrm{mg}$; folic acid, $0.69 \mathrm{mg}$; vitamin $\mathrm{B}_{12}, 0.01 \mathrm{mg}$; vitamin $\mathrm{D}_{3}$, 2,133 ICU; vitamin E, $16.53 \mathrm{IU}$; choline, $386 \mathrm{mg}$; menadione, $0.83 \mathrm{mg}$; copper, 0.0025\%; iodine, $0.003 \%$; iron, $0.01 \%$; manganese, $0.02 \%$; selenium, $0.00003 \%$; and zinc, $0.02 \%$ (Barnes et al., 2012).

Hogs were allowed ad libitum access to feed and water for six weeks prior to slaughter, and were weighed weekly to monitor growth. Barnes and others (2012) reported no differences in average daily gain and average daily feed intake. Following the six-week feeding study, all hogs were slaughtered at a commercial facility. Hot carcass weights were measured $(81.4 \pm 4.97 \mathrm{~kg})$, and carcasses were chilled for $24 \mathrm{~h}$ at $3-4{ }^{\circ} \mathrm{C}$. Pork loins were removed from the chilled carcass, packaged in non-gas permeable bags and transported on ice to the meats laboratory. 
Pork chops, located at the 10th and 11th thoracic vertebrae, were collected to score marbling and determine intramuscular, fatty acid content, results of which are reported elsewhere (Barnes et al., 2012). Loins (beginning with 3rd thoracic vertebra) were divided into thoracic and lumbar portions, deboned, immediately placed into non-permeable vacuum bags, sealed, and stored at $-20^{\circ} \mathrm{C}$. After $24 \mathrm{~h}$, frozen loins were cut with a band saw into $2.54 \mathrm{~cm}$ thick pork chops. Pork chops were repackaged in non-gas permeable vacuum sealed bags, randomly assigned for lab analyses and stored at $-20^{\circ} \mathrm{C}$ until analyses were conducted to minimize any change in loin quality over time (Hansen, Juncher, Henckel, Karlsson, \& Bertelsen, 2004). Length of frozen storage prior to these analyses did not exceed 120 days.

\subsection{Sample Preparation and Thermal Processing}

Prior to all analyses, designated pork chops were removed from the freezer, and held at $4^{\circ} \mathrm{C}$ for 14 days in dark storage to simulate vacuum aging before distribution to retail stores. Pork chops remained in the vacuum package during the aging process, and were then placed on Styrofoam trays, wrapped with oxygen-permeable, polyvinyl chloride film and refrigerated at $4^{\circ} \mathrm{C}$ for a maximum of 7 days. Proximate composition was confirmed on day 1 , and pork quality indicators were measured on days $1,3,5$, and 7 .

Pork chops used for proximate composition were cooked 1 day after transfer to Styrofoam trays. Full chops were placed in individual glass baking pans and cooked in $118 \mathrm{ml}$ water. All chops were cooked at $165^{\circ} \mathrm{C}$ for approximately $45 \mathrm{~min}$ or until reaching an internal temperature of at least $70^{\circ} \mathrm{C}$. A Beckman Industrial Data logger (Model 205; Beckman Instruments, Fullerton, CA) was used to monitor internal chop temperatures during the cooking process; thermometer probes were placed in the center of the chops.

\subsection{Sample Analyses}

\subsubsection{Proximate Composition}

Proximate composition (crude fat, crude protein, moisture, and ash) of cooked loin samples was determined on day 1 and conducted according to Association of Official Analytical Chemists methods (1995). Results are expressed as $\mathrm{g} / 100 \mathrm{~g}$ (wet basis). Crude fat of raw muscle was also determined. Fat was measured using the Soxhlet extraction method, and protein was measured using the Kjeldahl assay. Moisture was determined by weight differences of fresh and dry samples after $16 \mathrm{~h}$ of drying at $70^{\circ} \mathrm{C}$ at a partial vacuum pressure of $20 \mathrm{~mm} \mathrm{Hg}$. Ash content was determined by weight differences in samples incinerated at $550^{\circ} \mathrm{C}$ for 24 hours in a muffle furnace.

\subsubsection{Loin $\mathrm{pH}$}

The $\mathrm{pH}$ of the pork loin was assessed on days $1,3,5$, and 7 prior to and after cooking to determine initial loin $\mathrm{pH}$ and changes in $\mathrm{pH}$ over time. Each chop was divided into four quadrants; $\mathrm{pH}$ assessments were taken at the center portion of each quadrant using a $\mathrm{pH}$ probe (Model 350, Corning Inc.; Corning NY, USA).

\subsubsection{Texture Analysis}

Shear force was conducted on cooked samples following 1, 3, 5, and 7 days of storage. After cooking, muscle sections were cored $(1.27 \mathrm{~cm}$ dia.) using a uniform coring instrument and measured for shear force. The Warner-Bratzler attachment on a texture analyzer (Model TA-HDi, Texture Technologies Corp., Scarsdale, NY) was used to determine the peak force required to shear one core as a measure of tenderness.

The texture analyzer parameters were as follows: pre-test speed $=2 \mathrm{~mm} / \mathrm{sec}$; test speed $=5 \mathrm{~mm} / \mathrm{sec}$; post test speed $=5 \mathrm{~mm} / \mathrm{sec}$; distance $=25 \mathrm{~mm}$; force $=100 \mathrm{~g}$; time $=5 \mathrm{sec}$; load cell $=50 \mathrm{~kg}$.

\subsubsection{Lipid Oxidation}

Lipid oxidation of pork loin was measured by the thiobarbituric acid reactive substances (TBARS) test. Samples were measured in triplicate for lipid oxidation after cooking on days 1, 3, 5, and 7 using a modified method described by $\mathrm{Yu}$ and Sinnhuber (1957). Absorbance was read at $535 \mathrm{~nm}$ using an UV/Vis spectrophotometer (model DU530, Beckman Instruments, Fullerton, CA), and the concentration of TBARS was calculated using the molar absorptivity of malondialdehyde (MDA; $156,000 \mathrm{M}^{-1} \mathrm{~cm}^{-1}$ ). Relative MDA was calculated for comparison to the control Day 1 pork sample mean.

\subsubsection{Instrumental Color Analysis}

Meat samples (raw and cooked) were tested for color change at days 1,3,5, and 7 using a standard chromameter (8-mm aperture, Model CR-300; Minolta Camera Co. Ltd., Osaka Japan.) Evaluations were conducted at the center of each muscle section prior to and after cooking. The following values were recorded: lightness $\left(\mathrm{L}^{*}\right.$-scale: $0-100)$, yellowness $\left(\mathrm{b}^{*}\right.$-scale: $\left.-60-+60\right)$, and redness $\left(\mathrm{a}^{*}\right.$ - scale: $\left.-60-+60\right)$. 


\subsubsection{Statistical Design}

The experimental unit for all analyses was pen ( $\mathrm{n}=5$ per diet). The evaluations for the storage study included $\mathrm{pH}$, color, texture, and TBARS, which were all completed in triplicate. The main effects of diet (CLA vs. SBO) and day (days 1, 3, 5 and 7) were analyzed by analysis of variance (ANOVA) along with their interactions (diet*day). Student's t-test was used to separate means of statistically-different parameters and interactions. All data were analyzed at a 5\% level of significance using JMP 10 software (SAS Institute, Cary, NC, USA) and reported as mean values \pm standard error of the mean, unless otherwise indicated.

\section{Results and Discussion}

\subsection{Proximate Composition}

Proximate composition of cooked pork loin chops from control and CLA hogs revealed no significant differences $(\mathrm{P}>0.05)$ in moisture, ash, protein, or fat (Table 2). We hypothesized that fat concentration in the control and CLA chops would be different because others have observed that CLA increased marbling and that CLA may alter fat deposition through PPAR $\gamma$ gene expression when supplemented in finishing hog feed; however, the fat content of CLA loin samples in this current study were not significantly different from the control. Our results are in agreement with Barnes et al. (2012) results where relative gene expression for intramuscular adipocyte markers of differentiating adipocytes (PPAR $\gamma$ ) and mature adipocytes were measured on rib and loin meat from the same animals used in this current study and did not show significant differences $(P>0.05)$. However, the expression of these genes was numerically greater in CLA-fed hogs than in SBO-fed hogs; this trend may be indicative of greater intramuscular adipose tissue compared to subcutaneous adipose tissue which was decreased in our CLA-fed hogs (Barnes et al., 2012). In addition, Wiegand et al. (2002) reported increased fat deposition with increasing weight gain of CLA-fed hogs. It is likely that this increase was because CLA was included at $1.25 \%$ (vs. $1.0 \%$ in this current study) and feeding duration was based on weight gain before slaughter (Wiegand et al., 2002). It is possible that increasing the sample size and feeding duration of this present study would have yielded significant results.

Table 2. Proximate composition ${ }^{\mathrm{a}}$ ( $\mathrm{g} / \mathrm{kg}$ sample) of cooked pork loin chops from SBO control and CLA pigs

\begin{tabular}{llll}
\hline & SBO & CLA & P-value \\
\hline Moisture, cooked & $589.4 \pm 3.1$ & $574.5 \pm 8.6$ & 0.143 \\
Protein, cooked & $345.4 \pm 9.3$ & $342.4 \pm 7.9$ & 0.810 \\
Ash, cooked & $6.5 \pm 0.9$ & $7.6 \pm 0.7$ & 0.356 \\
Fat, cooked & $53.9 \pm 7.1$ & $73.0 \pm 11.4$ & 0.193 \\
Fat, raw $^{\mathbf{b}}$ & $28.1 \pm 4.8$ & $37.9 \pm 4.1$ & 0.163 \\
\hline
\end{tabular}

${ }^{\text {a }}$ Values are given as mean scores \pm SEM ( $n=5$ per diet).

${ }^{\mathrm{b}}$ For comparison, fat composition of raw samples was also determined.

\subsection{Loin $\mathrm{pH}$}

Values for raw and cooked loin $\mathrm{pH}$ over a storage period of 7 days are presented in Table 3. For the SBO control and treatment groups, means ranged from 5.69 to 6.56, and all values were considered within acceptable pork pH ranges (Bendall \& Swatland, 1988). Raw and cooked loin samples showed an increase in loin $\mathrm{pH}$ between days 3 , 5 , and $7(\mathrm{P}<0.001)$, independent of diet type. Loin $\mathrm{pH}$ is commonly used in the pork industry as a primary indicator of loin quality and is correlated to attributes such as color and water-holding capacity (Huff-Lonergan et al., 2002). At higher $\mathrm{pH}$ values, pork tends to have better textural quality; however, a higher $\mathrm{pH}$ may also reduce shelf-life due to color changes and a predisposition to support the growth of spoilage organisms (Holmer et al., 2009). The initial loin $\mathrm{pH}$ measurement is a reflection of slaughter procedures and stress response evident during the perimortem period. As the meat ages, protein breakdown produces free amino acids that lead to an increase in $\mathrm{pH}$. The elevation of $\mathrm{pH}$ during storage may also be due to the natural spoiling effect that occurs within muscle.

\subsection{Shear Force}

Pork loin tenderness is an important attribute in relation to consumer acceptability. Tenderness within the loin was measured by the Warner Bratzler shear force test, which is a measurement of the amount of force needed to shear a $1.27-\mathrm{cm}$ dia. core (Table 3). The higher the instrumental shear force value is, the tougher the meat product is likely to be. Changes in texture over time $(\mathrm{P}=0.017)$, with texture scores improving with storage time, is 
consistent with reported studies (Huff-Lonergan et al., 2002). The shear force necessary to cut CLA samples were significantly less $(P=0.032)$ than control samples; indicating that the CLA samples were more tender. The CLA loins appeared to contain more lipid (3.8vs. $2.8 \mathrm{~g} / 100 \mathrm{~g}$ sample) and tended to have greater marbling scores ( $\mathrm{P}=$ 0.069) (Barnes et al., 2012). Some studies have shown that there is a negative relationship between marbling scores and shear force (Huff-Lonergan et al., 2002).

Table 3. Mean values of $\mathrm{pH}$ (raw and cooked), texture by shear force (cooked) and lipid oxidation by relative malondialdehyde (MDA)/kg sample) test (cooked) on pork loin chops from SBO control and CLA pigs over a 7 d storage period

\begin{tabular}{lllll}
\hline & $\begin{array}{l}\text { pH } \\
\text { (raw) }\end{array}$ & $\begin{array}{l}\text { pH } \\
(\text { cooked) }\end{array}$ & $\begin{array}{l}\text { Shear Force } \\
(\mathbf{N})\end{array}$ & $\begin{array}{l}\text { Relative } \\
\text { MDA }\end{array}$ \\
\hline SBO & $6.06 \pm 0.08$ & $6.19 \pm 0.05$ & $22.26 \pm 0.74^{\mathrm{a}}$ & $0.92 \pm 0.06$ \\
CLA & $6.02 \pm 0.07$ & $6.21 \pm 0.06$ & $20.52 \pm 0.44^{\mathrm{b}}$ & $0.89 \pm 0.05$ \\
\hline Day 1 & $5.69 \pm 0.02^{\mathrm{d}}$ & $5.98 \pm 0.06^{\mathrm{c}}$ & $23.50 \pm 1.09^{\mathrm{a}}$ & $0.99 \pm 0.06^{\mathrm{a}}$ \\
Day 3 & $5.83 \pm 0.04^{\mathrm{c}}$ & $6.00 \pm 0.02^{\mathrm{c}}$ & $20.77 \pm 0.60^{\mathrm{ab}}$ & $1.04 \pm 0.05^{\mathrm{a}}$ \\
Day 5 & $6.21 \pm 0.07^{\mathrm{b}}$ & $6.25 \pm 0.04^{\mathrm{b}}$ & $21.41 \pm 0.93^{\mathrm{b}}$ & $0.87 \pm 0.09^{\mathrm{ab}}$ \\
Day 7 & $6.42 \pm 0.05^{\mathrm{a}}$ & $6.56 \pm 0.04^{\mathrm{a}}$ & $19.89 \pm 0.52^{\mathrm{b}}$ & $0.72 \pm 0.09^{\mathrm{b}}$ \\
\hline P-value day & $<0.001$ & $<0.001$ & 0.017 & 0.017 \\
P-value diet & 0.486 & 0.602 & 0.032 & 0.264 \\
P diet*day & 0.114 & 0.782 & 0.352 & 0.258 \\
\hline
\end{tabular}

Values are given as mean scores \pm SEM ( $n=5$ per diet) for each treatment on each treatment day. ${ }^{\mathrm{a}, \mathrm{b}, \mathrm{c}, \mathrm{d}}$ Values with different letters within columns are significantly different $(\mathrm{P}<0.05)$.

\subsection{Lipid Oxidation}

Dietary inclusion of unsaturated fatty acids (UFA) in finishing hog feed may increase the UFA profile of the meat, and an increase in UFAs may affect the shelf-life stability of the meat due to a greater predisposition to lipid oxidation (Cardenia et al., 2011). CLA has been used to combat increased UFA in meat as it inhibits stearoyl-CoA desaturase (Park et al., 2000) and decreases the iodine value of pork (Corino, Magni, Pastorelli, Rossi, \& Mourot, 2003). Therefore, the TBARS test was used to screen samples for lipid oxidation by measuring MDA (Table 3). Results showed that there were changes in relative MDA over time $(\mathrm{P}=0.017)$; however, changes in relative MDA were independent of diet $(\mathrm{P}=0.264)$. Wiegand and others $(2002)$ reported that hogs fed CLA diets produced chops that had lower TBARs values than hogs fed a traditional diet. They attributed this improvement to the reduction of polyunsaturated fatty acids and the increase in saturated fatty acids of the CLA chops because UFA are more susceptible to oxidation (Wiegand et al., 2002). Fatty acid profile of samples used in this study were reported elsewhere (Barnes et al., 2012); however, fatty acid analysis confirmed that the CLA pork samples used in this current study had significantly more saturated fatty acids than the control samples $(\mathrm{P}=0.006)$, but there was not a significant reduction in polyunsaturated fatty acids $(\mathrm{P}=0.500)$ (Barnes et al., 2012).

\subsection{Color}

Color provides a direct indication of overall pork quality as well as spoilage. Consumers determine the freshness and quality of the loin by evaluating the amount of discoloration. Oxidation of myoglobin (indicates pork quality), the main protein responsible for protein color, is evident as an increase in the $\mathrm{L}^{*}$ value (lightness), and a decrease in $\mathrm{a}^{*}$ (redness) and $\mathrm{b}^{*}$ (yellowness) values within the muscle (Mancini et al., 2005). Color for raw and cooked loin samples over time and results are presented in Table 4. Significant $(p<0.001)$ color changes were seen in raw and cooked lightness $\left(\mathrm{L}^{*}\right)$ and yellowness $\left(\mathrm{b}^{*}\right)$ values over time regardless of diet. Lightness decreased over time for raw and cooked samples; whereas, yellowness decreased in raw samples and increased in the cooked samples as storage time increased. Lightness is influenced by water retention in the samples (Sanchez del Pulgar, Gazquez, \& Ruiz-Carrascal, 2012); it is likely moisture was lost from the samples over the storage period resulting in a reduction of $\mathrm{L}^{*}$ values. Lightness is also influenced by $\mathrm{pH}$ and storage time, with darker products forming as $\mathrm{pH}$ and time increase (Huff-Lonergan et al., 2002). Wiegand and others (2002) reported that hogs fed CLA diet had 
higher $b^{*}$ values than hogs fed the control diet, which is indicative of a more yellow product. In our study, $b^{*}$ value of the raw CLA chops was numerically greater than the control diet, but was not different $(\mathrm{P}=0.290)$. There was a significant reduction in redness $\left(\mathrm{a}^{*}\right)$ and yellowness $\left(\mathrm{b}^{*}\right)(\mathrm{P}=0.027$ and $\mathrm{P}>0.001$, respectively) of the raw chops over the storage period which is associated with the increase in $\mathrm{pH}$ typical during aging and simulated retail display (Holmer et al., 2009; Mancini \& Hunt, 2005). Thiel et al. (1998) suggested that dietary CLA may protect meat color; however, results of this study indicate that loin color was not affected by diet.

Table 4. Raw and cooked $\mathrm{L}^{*}, \mathrm{a}^{*}$, and $\mathrm{b}^{*}$ values of pork loin chops from SBO control and CLA pigs through a 7-d storage period

\begin{tabular}{|c|c|c|c|c|}
\hline & & $L^{*}$ & $a *$ & $b^{*}$ \\
\hline \multirow{9}{*}{$\underset{\mathscr{E}}{\mathbb{E}}$} & SBO & $56.99 \pm 0.82$ & $9.67 \pm 0.33$ & $9.85 \pm 0.27$ \\
\hline & CLA & $56.48 \pm 0.74$ & $10.09 \pm 0.26$ & $10.23 \pm 0.34$ \\
\hline & Day 1 & $61.37 \pm 0.84^{\mathrm{a}}$ & $10.71 \pm 0.34^{\mathrm{a}}$ & $11.03 \pm 0.39^{\mathrm{a}}$ \\
\hline & Day 3 & $56.04 \pm 0.68^{b}$ & $8.95 \pm 0.45^{\mathrm{a}, \mathrm{b}}$ & $10.77 \pm 0.29^{a}$ \\
\hline & Day 5 & $54.31 \pm 0.75^{b}$ & $9.97 \pm 0.36^{\mathrm{a}, \mathrm{b}}$ & $9.22 \pm 0.42^{b}$ \\
\hline & Day 7 & $55.22 \pm 0.35^{b}$ & $9.90 \pm 0.39^{b}$ & $9.14 \pm 0.24^{b}$ \\
\hline & P-value day & $<0.001$ & 0.027 & $<0.001$ \\
\hline & P-value diet & 0.480 & 0.287 & 0.290 \\
\hline & P diet*day & 0.953 & 0.376 & 0.593 \\
\hline \multirow{9}{*}{ 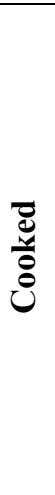 } & SBO & $67.33 \pm 0.70$ & $5.75 \pm 0.17$ & $11.64 \pm 0.21$ \\
\hline & CLA & $66.21 \pm 0.61$ & $6.01 \pm 0.12$ & $11.34 \pm 0.20$ \\
\hline & Day 1 & $70.45 \pm 0.66^{\mathrm{a}}$ & $6.27 \pm 0.18^{\mathrm{a}}$ & $10.90 \pm 0.10^{b}$ \\
\hline & Day 3 & $66.56 \pm 0.57^{b}$ & $5.78 \pm 0.15^{\mathrm{a}, \mathrm{b}}$ & $10.79 \pm 0.17^{\mathrm{b}}$ \\
\hline & Day 5 & $64.84 \pm 0.59^{\mathrm{b}}$ & $5.93 \pm 0.16^{\mathrm{a}, \mathrm{b}}$ & $11.93 \pm 0.29^{\mathrm{a}}$ \\
\hline & Day 7 & $65.23 \pm 0.68^{b}$ & $5.54 \pm 0.27^{b}$ & $12.35 \pm 0.20^{\mathrm{a}}$ \\
\hline & P-value day & $<0.001$ & 0.101 & $<0.001$ \\
\hline & P-value diet & 0.085 & 0.223 & 0.151 \\
\hline & $P$ diet*day & 0.876 & 0.964 & 0.680 \\
\hline
\end{tabular}

Values are given as mean scores \pm SEM ( $\mathrm{n}=5$ per diet) for each treatment on each treatment day.

${ }^{\mathrm{a}, \mathrm{b}}$ Values with different letters within columns are significantly different $(\mathrm{P}<0.05)$.

In conclusion, the results of this study showed that CLA supplementation of finishing diets results in pork quality similar to that of traditional diets. Because addition of CLA to finishing hog feed did not affect product quality indicators, it is difficult to justify the added expense of CLA supplementation to the diet. However, there may still be times when adding CLA to the diet is beneficial (i.e. to increase firmness of meat, especially pork belly cuts). It is possible that increasing the sample size of the study would yield more significant differences in quality parameters.

\section{Acknowledgements}

This work was funded in part by the West Virginia University Senate Grants for Research and The USDA Hatch Program (project nr WVA00622). This work is published with the approval of the Director of the West Virginia Agriculture and Forestry Experiment Station as scientific paper no. 3162.

\section{References}

Aberle, E. D., Forrest, J. C., Gerrard, D. F., \& Mills, E. W. (2001). Principles of Meat Science (4th edn). Dubuque, Iowa: Kendall Hunt Publishing.

Association of Official Analytical Chemists. (1995). Official Methods of Analysis (16th edn). Association of Official Analytical Chemists, Washington, D.C. 
Barnes, K. M., Winslow, N. R., Shelton, A. G., Hlusko, K. C., \& Azain, M. J. (2012). Effect of dietary conjugated linoleic acid on marbling and intramuscular adipocytes in pork. J Anim Sci, 90, 1142-1149. http://dx.doi.org/10.2527/jas.2011-4642

Bendall, J. R., \& Swatland, H. J. (1988). A review of the relationships of $\mathrm{pH}$ with physical aspects of pork quality. Meat Sci, 24, 85-126. http://dx.doi.org/10.1016/0309-1740(88)90052-6

Brandebourg, T. D., \& Hu, C. Y. (2005). Isomer-specific regulation of differentiating pig preadipocytes by conjugated linoleic acids. J Anim Sci., 83, 2096-2105.

Cardenia, V., Rodriguez-Estrada, M. T., Cumella, F., Sardi, L., Casa, G. D., \& Lercker, G. (2011). Oxidative stability of pork meat lipids as related to high-oleic sunflower oil and vitamin E diet supplementation and storage conditions. Meat Sci, 88, 271-279. http://dx.doi.org/10.1016/j.meatsci.2010.12.034

Corino, C., Magni, S., Pastorelli, G., Rossi, R., \& Mourot, J. (2003). Effect of dietary conjugated linoleic acid supplementation in sows on performance and immunoglobulin concentration in piglets. J Anim Sci, 81, 2219-2229. http://dx.doi.org/10.2527/jas.2008-1232

Dugan, M. E. R., Aalhus, J. L., Jeremiah, L. E., Kramer, J. K. G., \& Schaefer, A. L. (1999). The effects of feeding conjugated linoleic acid on subsequent pork quality. Canadian J Anim Sci, 79, 45-51. http://dx.doi.org/10.4141/A98-070

Dugan, M. E. R., Aalhus, J. L., Schaefer, A. L., \& Kramer, J. K. G. (1997). The effect of conjugated linoleic acid on fat to lean repartitioning and feed conversion in pigs. Canadian J Anim Sci, 77, 723-725. http://dx.doi.org/10.4141/A97-084

Dugan, M. E. R., Kramer, J. K. G., \& Aalhus, J. L. (2004). Conjugated linoleic acid pork research. Am J Clin Nut, $79,1212 \mathrm{~s}-1216 \mathrm{~s}$

Hansen, E., Juncher, D., Henckel, P., Karlsson, A., \& Bertelsen, G. (2004). Oxidative stability of chilled pork chops following long term freeze storage. Meat Sci, 68, 479-484. http://dx.doi.org/10.1016/j.meatsci.2004.05.002

Holmer, S. F., McKeith, R. O., Boler, D. D., Dilger, A. C., Eggert, J. M., Petry, D. B., ... Killefer, J. (2009). The effect of $\mathrm{pH}$ on shelf-life of pork during aging and simulated retail display. Meat Sci, 82, 86-93. http://dx.doi.org/10.1016/j.meatsci.2008.12.008

Huff-Lonergan, E., Baas, T. J., Malek, M., Dekkers, J. C., Prusa, K., \& Rothschild, M. F. (2002). Correlations among selected pork quality traits. J Anim Sci, 80, 617-627.

Jiang, Z. Y., Yang, L., Jiang, S. Q., Lin, Y. C., Zhong, W. J., \& Zheng, C. T. (2010). Conjugated linoleic acid differentially regulates fat deposition in backfat and longissimus muscle of finishing pigs. J Anim Sci, 88, 1694-1705. http://dx.doi.org/10.2527/jas.2008-1551

Larsen, S. T., Swan, J. E., Sparks, J. C., Wiegand, B. R., \& Parrish, F. C. J. (2009). Dietary conjugated linoleic acid changes belly and bacon quality from pigs fed varied lipid sources. J Anim Sci, 87, $285-295$. http://dx.doi.org/10.2527/jas.2008-1213

Lonergan, S. M., Stalder, K. J., Huff-Lonergan, E., Knight, T. J., Goodwin, R. N., Prusa, K. J., \& Beitz, D. C. (2007). Influence of lipid content on pork sensory quality within pH classification. J Anim Sci, 85, 1074-1079.

Mancini, R. A., \& Hunt, M. C. (2005). Current research in meat color. Meat Sci, 71, $100-121$. http://dx.doi.org/10.1016/j.meatsci.2005.03.003

Moya-Camarena, S. Y., Vanden-Heuvl, J. P., Blachard, S. G., Leesnitzer, L. A., \& Belury, M. A. (1999). Conjugated linoleic acid is a potent naturally occurring ligand and activator of PPAR. J Lipid Res, 40, 1426-1433.

Park, Y., Storkson, J. M., Ntambi, J. M., Cook, M. E., Sih, C. J., \& Pariza, M. W. (2002). Inhibition of hepatic stearoyl-CoA desaturase activity by trans-10, cis-12 conjugated linoleic acid and its derivatives. Biochim Biophys Acta, 1486, 285-292.

Rosen, E. D., Sarraf, P., Troy, A. E., Bradwin, G., Moore, K., Milstone, D. S., .. Mortensen, R. M. (1999). PPAR gamma is required for the differentiation of adipose tissue in vivo and in vitro. Mol Cell, 4, 611-6173.

Sanchez del Pulgar, J., Gazquez, A., \& Ruiz-Carrascal, J. (2012). Physico-chemical, textural and structural characteristics of sous-vide cooked pork cheeks as affected by vacuum, cooking temperature, and cooking time. Meat Sci, 90, 828-835. http://dx.doi.org/10.1016/j.meatsci.2011.11.024 
Thiel, R. L., Sparks, J. C., Wiegand, B. R., Parrish, F. C., \& Evan, R. C. (1998). Conjugated linoleic acid improves performance and body composition in swine. J Anim Sci, 76 (Suppl. 2), 57 (Abstr.).

Wiegand, B. R., Larsen, S. T., Baas, T. J., Parrish, F. C. J., \& Swan, J. E. (2001). Conjugated linoleic acid improves feed efficiency, decreases subcutaneous fat, and improves certain aspects of meat quality in stress-genotype pigs. J Anim Sci, 79, 2187-2195.

Wiegand, B. R., Sparks, J. C., Parrish, F. C. Jr, \& Zimmerman, D. R. (2002). Duration of feeding conjugated linoleic acid influences growth performance, carcass traits, and meat quality of finishing barrows. [Duration of feeding conjugated linoleic acid influences growth performance, carcass traits, and meat quality of finishing barrows]. J Anim Sci, 80, 637-643

Wolins, N. E., Quaynor, B. K., Skinner, J. R., Tzekov, A., Park, C., Choi, K., \& Bickel, P. E. (2006). OP9 mouse stromal cells rapidly differentiate into adipocytes: characterization of useful new model of adipogenesis. $J$ Lipid Res, 47, 450-460.

Yu, T. C., \& Sinnhuber, R. O. (1957). 2-Thiobarbituric acid method for the measurement of rancidity in fishery products. Food Technol, 11, 104-108.

Zhou, X., Li, D., Yin, J., Ni, J., Dong, B., Zhang, J., \& Du, M. (2007). CLA differently regulates adipogensis in stromal vascular cells from porcine subcutaneous adipose and skeletal muscle. J Lipid Res, 48, 1701-1709. 